\title{
A Bajau Tradeswoman: Between Trade Networks and Marine Conservation Issues \\ (Review of Amphibious Anthropology: Engaging with Maritime Worlds in Indonesia by Annet P. Pauwelessen)
}

\author{
Slamet Subekti \\ Doctoral Program of History, Faculty of Humanities, \\ Diponegoro University, Indonesia
}

\begin{abstract}
This paper drawn the case study of Langkah, the Bajau tradewoman, to show how maritime people perform informal networks of exchanges and interdependencies acroos the sea. Its sheds light on a world that often escapes the attention of maritime research and policy making both in terms of scale and complexity. There is a persisting disparity between the relational performance of this sea-based Bajau world and the way in which it is captured and approached in maritime governance, including conservation policy and practice.
\end{abstract}

Received:

December 4, 2018

Accepted:

January 23, 2019

Corresponding Author:

slametsubekti01@gmail.com

Keywords: Bajau Tradeswoman; Trade Networks; Marine Conservation; Makassar Strait.

\section{Introduction}

Annet P. Pauwelessen's (ANP) dissertation entitled "Amphibious Anthropology: Engaging with Maritime Worlds in Indonesia" (Wageningen University 2017) explores and engages with the multiplicity of Makassar Strait maritime region as a complex and amphibious land-sea interface in which difference performances of human-marine relations meet. This paper is a review of chapter 3 of ANP's dissertation which presents the narrative of Langkah as a highly mobile and energetic businesswoman. Langkah's business involved in international trade in marine products, including marine species and ingredients to make illegal fish bombs. She was one of the most successful maritime traders in the region at the time, sustaining an extensive network of family and patron-client relationships in and beyond the coastal the waters of Berau.

ANP used a performative approach to showing Langkah's network as a dynamic association enacted in practice and movement. Her travels along the coast of north-eastern Kalimantan make clear that she maintained her network as a tangle of lines constituted of and by movement. This network as an associational and relational effect (Latour 2005) required her to be continuously on the move to associate with socially and spatially mobile actors and keep volatile relations aligned with her interests.

Langkah's very mobility was odds with Marine Protected Areas (MPA) development and The Nature Conservancy's (TNC) conservation planning that is based on spatially fixed notions of social-environmental relations, and issues of morality (legality) that are approached only from a land -and State-based perspective. This subject presents some empirical grounds for the relevance and urgency of a paradigmatic shift in conservation thinking, finding ways to engaging mobile maritime people like the Bajau. The solution to the "participation problem" will not lie in finding (more) ways to incorporate Bajau (or other mobile maritime people) into conservation schemes. The shift has to take place in conservation discourse itself.

This ethnographic account of a female Bajau trader's network as she sustained it in 2011-2013. Langkah's travels on the practices and movement entailed in enacting and maintaining an informal trade network, and her practice relations of business and family converge. The case of Langkah's trade network is particularly relevant in relation to marine conservation in Berau because it crosses the boundary between legal and illegal, formal and informal notions of organisations in fishing and trade. Langkah's movement illustrate the disparity between the mobility and fluidity of maritime trade networks, on the one hand, and spatial fixation of people, places and borders in the conservation discourse on the other.

\section{Studies on the Bajau Maritime Trade Networks}


Earlier studies have documented various attempts to regulate marine resources in Berau, such as the creation of marine protected areas (MPA) and monitoring and patrols to stop illegal fishing and trade in endangered species (Gunawan and Visser, 2012; Kusumawati and Visser, 2014). Reports that have been used as a basis for planning of the Berau MPA recommend active community participation in conservation management (Wiryawan et al., 2005; Bogor Agricultural University, TNC-WWF Joint Program, \& Berau District, 2009). However, in practice, engaging Berau's coastal people has remained difficult, particularly on the islands where the majority identifies with Bajau ethnicity.

Clifton and Majors (2012) link the recurrent failure to involve Bajau people in conservation work to the disparity between marine conservation policies and the Bajau way of life. The highly mobile lifestyle of the Bajau is at odds with the spatial and terrestrial bias inherent in contemporary marine conservation policies in Indonesia. Ethnographic insight in their sea-spanning relation and movement is relevant to understanding the maritime world that the conservation policies attempt to intervene, and manage.

Historical studies have shown that sea-spanning web of kindship and trade relationships are a constant feature of maritime life in Southeast Asia. Seafaring peoples of South Sulawesi - Makassarese, Bugis and Mandar - are renowned for sustainaing extensive, sea-based networks of commerce and exchange (Pelras, 1996; Butcher, 2004; Schwerdtner Mánez and Ferse, 2010; Sutherland, 2000). Bajau traders have had a crucial role in the historical development of centres of maritime commerce in Southeast Asia (Sather, 2002; Warren, 2007). Bajau women have been active participants in marine resource trade and, although their roles has been generally overlooked (Schwerdtner Máñez and Pauwelussen, 2016). Practices of fishing and trade among the Bajau often traverse national borders, as well as areas of restricted access, generating discussions of their legality and legitimacy (Adhuri and Visser, 2007; Stacey, 2007; Adhuri, 2013).

A recurring theme in the literature on maritime trade is the convergence of economic relations with networks of kinship and patronage that span across seas. Patron-client networks creates long-standing relations of mutual expectation and dependency in Indonesia's coastal areas (Meereboer, 1998; Pelras, 2000) and enable, but are also an effect of, geographical and socio-political mobility (Acciaioli, 2000). Through such trans-local and asymmetric networks of resource extraction and trade, local maritime livelihoods are linked to distant markets (Stacey, 2007; Ferse et al., 2012; Fabeko, 2013; Gaynor, 2005). Among Indonesia's maritime people, affinity and loyalty follow translocal relations of kinship, credit, and debt rather than the borders of a village or island (Kusumawati et al., 2013).

Although ethnographic studies in Southeast Asia have shown that fishing practices and their organizations often proceed through informal relations that shift and blur regulatory boundaries between insiders/outsiders and legal/illegal (Fabinyi et al., 2010; Ferse et al., 2012; Gunawan and Visser, 2012), the very concept of marine conservation as the establishment of spatial and legal boundaries remains largely uncontested in the maritime literature (Thorpe et al., 2011, see also Lowe, 2006; Walley, 2004). This paper sheds lights on the one of the main disparities by which sea-based Bajau webs of trade, kinship and credit relations and project for marine park development remain worlds apart.

ANP's approach to tracing Langkah's trade networks as an assembling of relations. This study focused on the figure of Langkah, follow her doing business and performing her network on Sarang Island and on her way into different spatial and social directions along the coast of northeastern Kalimantan. Furthermore, the marine conservation policy is discussed in Berau and how it is at odds with mobile trade networks such as Langkah's.

\section{Langkah's Maritime Trade Networks Crossed the Indonesia-Malaysia Border}

In ethnography account of Langkah's world of trade relations, the notion of network figures as a conceptual tool that helps with exploring the relational and performative nature of Langkah's trade practices, not as a model representing "a" reality. Such use of the concept of network resonates with the actor-network in the study of science and technology (STS), deployed to follow and describe how things, institutions, groups, are not only made up of heterogeneous material and semiotic elements, but also need to be performed, enacted, in order to subsist (Latour, 1996; Law and Hassard, 1999).

Following this line of though, the social network can be conceptualised as the effect of the associations of heteregeneous relations, and not some kind of "social facbric" that pre-exist people's practiced. Or rather, the social is the practice of association (Latour, 2005). In such performative and relational ontology of the social, social reality is contingent on relational practices that sustaine in the association and friction with the "sticky materiality of everyday life" (Tsing, 2005). The methodological consequence is that by following relational practices, one can trace how "social" (community, kinship) is enacted in different sites and situations, and who and what participates. Such approach fits an explorativeand anthropological 
methodology because it allows for following interlocators along their world-making practices, instead of defining for them what their world looks like.

The following is an description of a "day of doing business" from Sarang Island. In 2012, Langkah came to the island once or twice a month, staying for three to five days. During these days she moved from one house to the other, talking and drinking tea for hours with (old and new) trading partners. Visit to one of her main trading partners was typical of the way she works. The informality "doing business" as part of engaging with the other in a porpuseful way, associating relations of work, marriage alliances, weather, and ethnic affiliations. Although Langkah often framed her business in state of urgency, she took considerable time to conduct in an intimate and informal way, smoothening and arranging her relationship with stories, jokes, and gossip.

Langkah's world of maritime trade relations is a dynamic one, and she has mastered the skills of engaging in this flexibility and turning it to her advantage. But, this flexibility does not mean that "anything goes". Langkah's exchanges with Susi are guided by a patron-client relations. Although debt relations were crucial in sustaining Langkah's commercial network, so was the fulfillment of more traditional obligations associate with the role of patron. For example, Langkah paid the fine for the captain, keeping him out of jail, without expecting to be reimbursed. When he then tried to work with another patron, Langkah felt severely betrayed.

Unlike the Lindu case described by Acciaioli (2000), Bajau traders in Berau did not clearly differentiate between a primarily economic character of their relationship and their social interdependencies. Also, in most business exchanges, when not speaking Bajau, they use the general term "boss" for (male/female) Bajau or Mandar assuming patron roles, not making the clear distinction between bosses and patron as observed in southern Sulawesi societies (Acciaioli, 2000; Pelras, 2000).

Evidently, patron-client relation may shape exchanges, but they do not fixate people and things in particular places or positions. While Susi is a client to Langkah, but she also acts as the boss for her own clients (anak buah) on the island. Similarly, Langkah is patron and boss, but also a client to her ChineseMalaysian patron (tauke) in Tawau. The relational character of patron-client partnerships shows it as a dynamics association of mobile and sifthing social-material relations across the sea. As a middlewoman, Langkah mediates a diverse set of mobile and shifting relations. Keeping them to productive client and in line with her interests requires on going practice of association and mediation. For example, Langkah instructing Susi on caring the fish, translating distant market values, and mobilising her captains to move around the fish, ice, and fertiliser.

Patron-client arrangements are commonly seen as fun ways in which the volatility of maritime trade networks is stabilised - relations of debt, loyalty, and mutual expactation make for durable trade arrangements. But their relational character begs for continues enactment. Moreover, once relationally stabilised, the network does not stop moving. On the contrary, the forming and temporary stabilisation of Langkah's network-as association requires continuous movement - her mobilisation of others people as well as her own mobility. Practically the necessity of moving around the island to engage in face-to-face interactions and exchanges - crucial to sustain relations of trust and reciprocity. Also, by moving around, Langkah assembles information, orders, and tries to lure new trade partners into her network.

Giant clam (kima, tridacna gigas) is a highly valued commodity in Tawau, particularly on the Chinese-Malaysian market. Commercial trade of (wild) kima has been internationally banned because of the animal's status as a threatened species. However, during fieldwork researcher saw hundreds of kilos of dried clams were exported monthly from Berau to Malaysia. On Sarang Island, there was increasing competition between traders to obtain giant clams from the (mostly Bajau women) collectors. Langkah engaging in this trade was a very lucrative business for her. One kilogram bought for about 100,000 IDR in Sarang was sold for 180,000 IDR or more in Tawau. But the collectors were rather independent. Whatever they gleaned from the coral, they could sell for for the best bid. However, they do not necessarily opt for the highest bidder. Other items than cash could be more valuable items. Cash was a limited value on Sarang island anyway, as the informal island economy was to a large extent based on sharing and reciprocal exchanges.

Langkah also invested in sustaining relations of mutual affinity and affection with the women. She using a shared Bajau language and tracing common ancestry to overseas places, help in creating a sphere of intimacy. Sustaining this intimacy and promising new goods were some of practices that helped to stabilise Langkah's relations with the clam-collecting women, keeping these relations productive while she was absent. But again, this (temporary) stabilisation of her network was only realised on the condition of her constanly moving about. Keeping the women attached to her required Langkah to travel. Because promise were not enough, in the end she had to show up on the island, bringing from Malaysia a bag full of goodies. 
Langkah is a quintessential wayfarer in Ingold sense: "continually on the move (...) instantiated in the world as a line of travel, (sustaining) himself, both perceptually and materially, through active engagement with the country that opens up along his path" (Ingold, 2011: 150). The networks thus emerge as the crystallisation of activity and movement in a dynamic relational field (Ingold, 2011: 47). Langkah contantly adjusted to the configuration of routes and interests as they manifested in her network while travelling. She almost continuouesly keep track of her trading associates: her captains, the fish, the ice, the tauke in Tawau, and fish bosses on Sarang. Langkah with phone calls and visits mobilises and steered her network while moving along herself.

Historical accounts have documented waves of migration by Bajau families from the southern Philippines and Sabah southwards to the coast of northeastern Kalimantan (Sather, 1997; Warren, 2007). Rather than a one-way movement from A to B, this Bajau migration constitutes dynamic and moving a field of interaction and exchanges across a vast marine space. The historically grown network of relations based on notions of family and Bajau ethnicity motivates and mobilises loyalty and reciprocity in Langkah's network. Particularly apparent is the way she safeguards border passage for her and her valuables. She was maintaining productive relations with politicians, police and navy officers all along the trade route to Malaysia by appealling to a shared ancestry or ethnic background.

The coastal border area between Indonesia and Malaysia is populated by Bajau and other ethnic groups. The fact that people crossing borders this way continousely through the Indonesian-Malaysian coastal zone is an open secret. By skillfully mobilizing networks of collaboration that follow or mimic kinship relations, Langkah eases her movement in the gray area "illegal but licit" practices (Gunawan and Visser, 2012). This "twilight" route evades formal customs, but moves along informal relations with police and customs officers, may of whom she said are related to her by kinship or "Bajauness". This practice also includes crossing of her valuables and trade-family associates.

Langkah trade network involves the fusion of legal/illegal practices with formal/informal, family and business relations. It is important that in such a dynamic association, people affiliated more with trans-border relations of Bajau kinship and ethnicity (the expectations of loyalty and reciprocity that come with it) than with national borders or the rule of state law. In other words, in this apparent continuity of seascape, national borders and the rule of law seems arbitrary (Stacey, 2007).

\section{Langkah's Maritime Trade Networks and Marine Conservation Policy in Berau District, East Kalimantan}

Since 2003, international conservation agencies have been working to protect Berau's marine biodiversity in collaboration with the Berau district government. In 2005, these efforts resulted in the establishment of an MPA of 1.27 million ha, covering the Berau waters. During Annet P. Pauelessen's research in 2011-2013, the most prominent non-governmental organisations involved in marine conservation were WWF, TNC and locally based Bestari. All the three organisations have been involved in the initial collaboration of MPAs, but at the time of the research only TNC was explicitly oriented to the enhancement of MPA policy and practice by working towards collaboration with governmental partner and local communities. However, apart from TNC's community-based conservation policy and advocacy, the implementation of the Berau MPA has not resulted in the active participation of the majority of the people living in the islands and coastal villages of Berau (Chapter 4; Gunawan, 2012).

Since 2003, international conservation agencies have been working to protect the marine biodiversity of Berau in collaboration with the Berau district government. In 2005, this effort resulted in the establishment of a 1.27 million ha marine protected area, covering the waters of Berau. During ANP's research in 2011-2013, the most prominent non-governmental organizations involved in marine conservation were locally based WWF, TNC and Bestari. The three organizations have been involved in the initial collaboration of MPAs, but at the time of the research, only TNC was explicitly oriented towards improving MPA policies and practices by collaborating with government and local community partners. However, apart from TNC's community-based conservation policy and advocacy, the implementation of the Berau MPA has not resulted in the active participation of most of the people living in the Berau islands and coastal villages (see Chapter 4; Gunawan, 2012).

During the researcher fieldwork, TNC was in the process of conducting outreach activities with the communities regarding in the Berau MPA region. This outreach mostly revolves around explaining MPA zoning plan and acquiring local feedback. The zoning plan, drafted in 2011, was based on scientific data of critical habitats in need of conservation (Bogor Agricultural University, TNC-WWF Joint Program, \& Berau District, 2009). These habitats were proposed as the conservation zones within MPA, to be protected from 
all forms of exploitation (Interview staff TNC Marine, 30 January 2012). TNC then presented plans at the sub-district (kecamatan) level for public consultations (TNC Marine staff interviews, 30 January 2012). In every sub-district that was assigned a core zone, the local community was asked to provide input regarding how conservation rules should be locally implemented. This input was focused on the specific rules and rights of local fisher and the precise location and borders of the core zone within the sub-districts administrative borders (Interview Fisheries officer, 19 April 2011).

A TNC policy document on community outreach in Indonesian MPA reads that the success of marine conservation depends on "the active involvement of people and partners whose lives and livelihoods are linked to the natural systems we seek to conserve" (Soekirman et al., 2009: 6). The document underlines the importance of establishing relationships with local people based on mutual benefits and sharing, and applying sensitivity in regard to their cultural and economic realities. Yet, such noble intentions for a relational and culturally sensitive approach are compromised by the dominant ecosystem-based conservation schemes in which they are embedded. It should be stressed here that "protected areas must be integrated within a broad sustainable development system" (Soekirman et al., 2009: 9). In the case of Berau sustainable development has instead been ad hoc integrated ad hoc in an already established protected area, the design of which was based on ecological, and not social, assessment criteria (Wilson et al., 2010; Kusumawati, 2014: 30-35).

TNCs state objective is to "solve the problem" of exploitative fishing practices in Berau with a microcredit schemes, by empowering women and by appointing village representatives as mediators of conservation outreach (Soekirman et al., 2009: 13, 26). The everyday reality of patron-client relations, entrepreneurship, and mobile networks of loyalty and exchange described here thus remain beyond the horizan of TNC policy implementation. Unfortunately, the intention to be sensitive to local customs is not based on, or does it leads to, an exploration of the kind of cultural and economic realities to which policy implementation has to be sensitive.

MPA solutions are based on stereotypical perceptions of maritime realm in which fishery is a masculine affair, loyalty follows village borders, and illegal fishing is the work of an non-resident fishers driven by poverty. Pre-defined borders are used to divide "rightful insiders" from "intruding outsiders". However, in practice line of debt, loyalty, and collaboration traverse these borders, as the case of Langkah's network illustrates. In conservation management this also leads to the supposition that village - or islandbased communities are the only stakeholders for the use and management of Berau's marine resources, and that conservation borders need to be protected from outsiders. Such a view ignores the permeability or even arbitrariness of the boundaries of the Berau conservation area (Gunawan and Visser, 2012), and it negates the crucial role of patrons and traders in this region who can "make or break" conservation projects (Kusumawati, 2014).

The dependence upon patrons of the coastal population in Berau is common knowledge, but so far traders and patrons have been excluded from MPA policy-making in Berau (Kusumawati and Visser, 2014). Roving traders such as Langkah, who sustain networks are systematically cross borders and play the illegal field, are kept out of the conservation picture. To some extent they also excluded themselves, moving their practices deliberately out of view from administrators and conservationists alike. Langkah, for example, knew of conservation (the husband of one of her cousins even ran a local conservation initiative), but she chose not to be part of it. However, when the practices of middle(wo)man like Langkah is systematically precluded conservation policy and practices, their mobile networks are rendered invisible and intangible by design. This also entails the risk of excluding part of the coastal population that depends on, or affiliated with, these networks.

\section{Conclusion}

The study of maritime trade networks practiced by Langkah has shown three important findings. First, the ethnography of the performance Langkah's network illustrated the need for a relational approach to conservation outreach that takes into account the mobility and interdependence of social-material networks of maritime resources use and trade, instead of current approach that fixate people and maritime practices into place. A socially and spatially mobile network such as Langkah's is at odds with conservationists' notions of fixed places, boundaries, and "local" communities. The lines along with resource exploitation and trade are mobilised extend far beyond the border of Berau district into Malaysia, thus beyond the scope and influence of district-based conservation agencies. 
Second, the conservation agencies are concerned with the over-exploitation of endangered species and the widespread use of unsustainable fishing methods but their policies do not take into account the socially dynamic and spatially mobile networks in which these are enmeshed. It is important to understand and acknowledge how maritime resource use and trade are conditioned by the fluidity and permeability of legal/illegal distinction and sea-spanning relation of loyalty, debt, and ethnic affiliation.

Finally, engaging mobile maritime people like the Bajau people in conservation planning will remain difficult as long as conservation and practice was based spatially fixed notions of social-environmental relations, and issues of morality (legality) are approached from a land - and State-based perspective. The solution to the "participation problem" will not lie in finding (more) ways to incorporate Bajau (or other mobile maritime people) into the conservation schemes. The shift has to take place in the conservation discourse itself. Marine conservation research needs to start thinking about how conservation can re-invent itself to better relate to the mobility and performance of a maritime world.

\section{References}

Acciaioli, G. "Kinship and Debt: the Social Organization of Bugis Migration and Fish Marketing at Lake Lindu, Central Sulawesi." Bijdragen tot de Taal-, Land-, end Volkenkunde 156, No. 3 (2000): 588617.

Adhuri, D.S. "Traditional Modern Trepang Fisheries on the Border of the Indonesian and Australian Fishing Zones." In Makassan History and Heritage: Journeys, Encounters and Influences, edited by M. Clark and S.K. May, Canberra: ANU E-Press, 2013: 183-203.

Adhuri, D.S., and L.E. Visser. "Fishing in, Fishing Out: Transboundary Issues and the Territorialization of the Blue Space." Asia Pasific Forum 36, 2007: 112-145.

Butcher, J.G. The Closing of the Frontier. A History of the Maritime Fisheries of Southeast, c. 1850-2000. Leiden: KITLV Press, 2004.

Clifton, J., and C. Majors. "Culture, Conservation and Conflict: Perspectives on Marine Protection Among the Bajau of Southeast Asia." Society \& Natural Resources 25, No. 7 (2012): 716-725.

Fabinyi, M., M. Knudsen, and S. Segi. "Social Complexity, Ethnography and Coastal Resource Management in the Philippines." Coastal Management 38, No. 6 (2010): 617-632.

Ferse, S.C.A., L. Kniiweis, G. Krause, A. Maddulisa, and M. Glaser. "Livehoods of ornamental coral fisherman in South Sulawesi, Indonesia: implications for management." Coastal Management 40, No. 5 (2012): 525-555.

Gaynor, J. "The decline of small-scale fishing and the reorganization of livehood practices among Sama People in Eastern Indonesia." Michigan Discussion in Anthropology 15 (2005): 90-149.

Gunawan, B.I. Shrimp Fisheries and Aquaculture. Making a living in he Coastal Frontier of Berau, Indonesia. Ph.D. Thesis, Wageningen University, 2012.

Gunawan, B.I., and L.E. Visser. "Permeable boudaries: Outsiders and access to fishing grounds in the Berau Marine Protected Area." Anthropological Forum 22, No. 2 (2012): 187-207.

Ingold, T. Being Alive: Essays on Movement, Knowledge and Description. London: Routledge, 2011.

Kusumawati, R. Networks and Knowledge at the Interface: Governing the Coast of East Kalimantan, Indonesia. Ph.D. Thesis, Wageningen University, 2014.

Kusumawati, R., S.R. Bush., and L.E. Visser (2013). "Can patrons be bypassed? Frictions between local and global regulatory networks over shrimp aquaculture in East Kalimantan.” Society \& Natural Resouces 26 No. 8 (2013): 898-911.

Kusumawati, R., and L.E. Vesser (2014). "Collaboration or contention? Decentralized marine governance in Berau.” Anthropological Forum 24, No. 1 (2013): 21-46.

Latour, B. Aramis or the Love of Technology. Translated by C. Porter. Cambridge, MA: Harvard University Press, 1996.

Latour, B. Reassembling the Social: An Introduction to Actor-Network Theory. Oxford: Oxford University Press, 2005.

Law, J., and J. Hassard. Actor-Network Theory and After. Oxford: Blackwell, 1999.

Lowe, C. Wild Profusion: Biodiverstity Conservation in an Indonesian Archipelago. Princeton: Princeton University Press, 2006.

Meereboer, M.T. (1998). "Fishing for credit: patronage and debt relations in the Spermonde Archipelago, Indonesia." In Living Through Histories: Culture, History and Social Life in South Sulawesi, edited by K. Robinson. Canberra: ANU/RSPAS, 1998: 249-276.

Pelras, C. The Bugis. Oxford: Blackwell Publishing, 1996. 
Pelras, C. "Patron-client ties among the Bugis and Makassarese of South Sulawesi." Bijdragen tot de Taal-, Land-, en Volkenkunde 156, No. 3 (2000): 393-432.

Sather, C. "Commodity trade, gift exchange and the history of maritime nomadism in Southeastern Sabah." Nomadic Peoples 6, No. 1 (2002): 20-44.

Schwerdtner Manez, K., and A.P. Pauwelessen. "Fish is women's business too: looking at marine resource use through a gender lens." In Perspectives on Oceans Past: A hanbook of Marine Environmental History, edited by K. Schwerdtner Manez and B. Poulsen. New York: Springer, 2016: 93-211.

Stacey, N. Boats to Burn: Bajo Fishng Activity in the Australian Fishing Zone. Canberra: ANU E-Press, 2007.

Soekirman, T., E. Carter, H. Widodo, and L.M. Scherl. Community Development and Alaternative Livehoods Initiatives at TNC-Coral Triangle Centre Related Sites: Recommendations for the Future. Denpasar: The Nature Conservancy, 2009.

Bogor Agricultural University, TNC-WWF Joint Program and Berau District. "Studi Rencana Zonasi Pesisir dan Pulau-Pulau Kecil Kabupaten Berau Provinsi Kalimantan Timur.” Unpublished Report, 2009.

Thorpe, A., M. Bavinck, and S. Coulthard. "Tracking the debat around marine protected areas: key issues and the BEG framework." Environmental Management 47 (2011): 546-563.

Tsing, A. Friction. An Ethnography of Global Connection. Princeton/ Oxford: Princeton University Press, 2005.

Walley, C. Rough Waters: Nature and Development in an East African Marine Park. Princeton: Princeton University Press, 2004.

Warren, J.F. The Sulu Zone 1768-1898: The Dynamics of External Trade, Slavery, and Ethnicity in the Transformation of a Southeast Asian Maritime State, 2nd ed. Singapore: NUS Press, 2007.

Wilson, J., P.J. Mous, B. Wiryawan, and L.M. DeVantier. Report on a Rapid Ecological Assessment of the Derawan Islands, Berau District, East Kalimantan, Indonesia, October 2003. Denpasar: The Nature Conservancy, 2010.

Wiryawan, B., M. Khazali, and M. Knigh. Menuju kawasan konservasi laut Berau, Kalimantan-Timur: Status sumberdaya pesisir dan proses pengembangan. Jakarta: Program bersama kelautan Berau TNCWF-Mitra Pesisir/CRMP II USAID, 2005. 